\title{
Compositional and isotopic characteristics of hydrocarbons generated by a hydrothermal experiment simulating seafloor sediment alteration stepwise heating from 275 to $361^{\circ} \mathrm{C}$ at $30 \mathrm{MPa}$
}

\author{
SHINSUKE KAWAGUCCI ${ }^{1,2 *}$ and JEFFERY S. SEEWALD ${ }^{2}$ \\ ${ }^{1}$ Super-cutting-edge Grand and Advanced Research (SUGAR) Program, Institute for Extra-cutting-edge Science and \\ Technology Avant-garde Research (X-star), Japan Agency for Marine-Earth Science and Technology (JAMSTEC), \\ 2-15 Natsushima-cho, Yokosuka 237-0061, Japan \\ ${ }^{2}$ Department Marine Chemistry and Geochemistry (MC\&G), Woods Hole Oceanographic Institution (WHOI), \\ Woods Hole, MA 02543, U.S.A.
}

(Received March 1, 2019; Accepted May 28, 2019)

\begin{abstract}
We conducted a laboratory hydrothermal experiment that simulated generation of low molecular-weight hydrocarbons during seafloor sediment alteration at $275-361^{\circ} \mathrm{C}$ and $30 \mathrm{MPa}$. The abundance and carbon and hydrogen stable isotope composition of low molecular weight thermogenic hydrocarbons in the fluids were determined. In general, the abundance of $\mathrm{C}_{1}-\mathrm{C}_{4}$ alkanes increased with time. The abundance of $\mathrm{CH}_{4}$ relative to $\mathrm{C}_{2}-\mathrm{C}_{4}$ alkanes as reflected by $\mathrm{C}_{1} / \mathrm{C}_{2+}$ ratios showed progressive increases from 1.2 to 4.3 with continued sediment heating. Alkenes were enriched in early phase and decreased with time. Carbon isotope ratios $\left(\delta^{13} \mathrm{C}\right)$ of thermogenic $\mathrm{CH}_{4}$ ranged between $-42.0 \sim-24.2 \%$. Carbon isotope ratios of $\mathrm{C}_{2} \mathrm{H}_{6}$ and $\mathrm{C}_{3} \mathrm{H}_{8}$ were similar to each other throughout the experiment $\left(\delta^{13} \mathrm{C}=-28.0 \sim-20.3 \%\right.$ ). In general, the carbon isotope ratios of $\mathrm{C}_{1}-\mathrm{C}_{4}$ alkanes were more close to those of substrate organic matter in larger carbon numbers and at later periods of the experiment. Hydrogen isotope ratios $(\delta \mathrm{D})$ of $\mathrm{CH}_{4}$ varied from $-325 \sim-262 \%$, more negative than those expected at the isotope equilibrium between $\mathrm{CH}_{4}$ and $\mathrm{H}_{2} \mathrm{O}$. Compared with results from the experiment, natural hydrothermal fluids show higher $\mathrm{C}_{1} / \mathrm{C}_{2+}$ ratio, more diverse $\delta^{13} \mathrm{C}_{\mathrm{CH} 4}$ values among the fields, higher $\delta^{13} \mathrm{C}_{\mathrm{C} 2}$ values, and higher $\delta \mathrm{D}_{\mathrm{CH} 4}$ values. The differences likely result from lower maturity of the experimental fluid and biogenic methane contribution to the natural fluids.
\end{abstract}

Keywords: carbon isotope ratio, hydrogen isotope ratio, fluid-sediment interaction, low molecular-weight hydrocarbons, Okinawa Trough

\section{INTRODUCTION}

Low molecular-weight hydrocarbons (LHCs), particularly $\mathrm{CH}_{4}$, are ubiquitously present in subsurface sedimentary environments (Bernerd et al., 1976; Whiticar et al., 1986; Wakita and Sano, 1983). There are three origins for subsurface LHCs with respect to carbon sources and processes: thermogenic, biogenic, and abiotic processes (Whiticar et al., 1986; Welhan and Lupton, 1987; Schoell, 1988; Sherwood Lollar et al., 2002; Fu et al., 2007; Proskurowski, 2010; McCollom et al., 2010; Taran et al., 2010; Kawagucci et al., 2013; Etiope and Sherwood Lollar, 2013; Etiope and Schoell, 2014). For example, thermogenic LHCs originate from chemical decomposition of organic matter at high temperature. Subsurface LHCs serve as fossil fuel for modern human activity (Tissot and Welte, 1978), suggest microbial activity under extreme physical-chemical condition (Stevens and

*Corresponding author (e-mail: kawagucci@jamstec.go.jp)

Copyright $@ 2019$ by The Geochemical Society of Japan.
McKinley, 1995; McCollom, 1999; Takai et al., 2008), and imply how chemical evolution driving birth of life occurs on prebiotic planet (Proskurowski et al., 2008; McCollom, 2013). Understanding origin of the subsurface LHCs thus provides us clues in broad spectrum of life-earth linkages.

Geochemical characteristics of LHCs have been used widely as a diagnostic tool for deducing subsurface conditions and processes including the origin of LHCs (Schoell, 1988; Chung et al., 1988; Sakata et al., 1997; Prinzhofer and Pernaton, 1997; Whiticar, 1999; Cruse and Seewald, 2006; Proskurowski et al., 2008; Proskurowski, 2010; Etiope and Sherwood Lollar, 2013; Kawagucci et al., 2013). More accurate interpretations of the origin of LHCs can be achieved using multiple geochemical tracers such as abundance and carbon and hydrogen isotope composition of each LHC (Etiope and Sherwood Lollar, 2013; Kawagucci et al., 2013). This approach requires preceding understandings of the possible diversity of isotopic and chemical composition of LHCs derived from each origin. Whereas the stable isotopic composition of 
$\mathrm{CH}_{4}$ associated with microbial methanogenesis has been investigated in detail with respect to the mechanisms and relevant environmental factors using laboratory experiments, theoretical calculations, and field observations (Sugimoto and Wada, 1995; Valentine et al., 2004; Penning et al., 2005; Stolper et al., 2014; Kawagucci et al., 2014; Wang et al., 2015; Okumura et al., 2016), there are relatively few experimental studies for stable isotopic and chemical composition of thermogenic LHCs in hydrothermal systems.

This study uses laboratory experiments to investigate the geochemical characteristics of thermogenic LHCs originating from the interaction of seawater saline fluids and unconsolidated seafloor sediment deposited under deep-sea hydrothermal condition. Thermogenic LHCs characteristics, frequently referred to interpret compositional and isotopic characteristics of LHCs in deep-sea sediment-associated hydrothermal vent fluids, have been established based on the observation of petroleum fields (Schoell, 1980; Whiticar et al., 1986; Etiope and Sherwood Lollar, 2013). However, it may be problematic because the petroleum originates mainly from kerogen and is more or less a mixture with biogenic methane (Sakata et al., 1997; Prinzhofer and Pernaton, 1997). From this viewpoint, experimental characterization has an advantage at conditions-controlled simulation for a target process, LHCs generation through hydrothermal fluid-sediment interaction, and can avoid any obscure from complex information imprinted in natural samples. However, some of experiments that attempted to characterize thermogenic LHCs (e.g., Sackett, 1978; Berner et al., 1995; Seewald et al., 1998) may involve reactions, which are unlikely to occur in deep-sea subsurface environment, due to uses of reactive materials such as stainless-steels and/or presence of vapor phase within the experimental apparatus (McCollom and Seewald, 2007). Previous studies used the chemically-inert apparatus for simulation of hydrothermal fluid-sediment interaction and reported abundance and carbon isotope ratio of thermogenic methane (Thornton and Seyfried, 1987; Seewald et al., 1990, 1994). This study provides more comprehensive geochemical dataset for thermogenic LHCs that includes $\mathrm{C}_{1}-\mathrm{C}_{4}$ hydrocarbons abundance and their carbon and hydrogen isotope ratios. The dataset obtained is useful not only to deduce geochemical origin of subsurface LHCs but also to discuss geochemical condition of subsurface hot zone at sediment-covered hydrothermal systems.

\section{Materials AND Methods}

\section{Hydrothermal experiment}

The experiment in this study is hereafter called OTS (Okinawa Trough Sediment experiment). OTS was con- ducted in October-December 2010 at Woods Hole Oceanographic Institution (WHOI). A flexible gold reactioncell apparatus (Seyfried et al., 1987), used in this study, can simulate the interaction among whole solid and aqueous compounds that are tightly involved to LHCs behavior under hydrothermal condition (Seewald, 2003). The apparatus consists of a gold reaction cell equipped with $\mathrm{TiO}_{2}$ fittings connecting with a capillary exit tube and sampling valve, an outer stainless-steel vessel, and a heating shell. The chemically inert reaction cell minimizes reactions unlikely occurring in nature while external pressure to compress the flexible cell prohibits vapor phase formation.

The OTS involved heating a sample of seafloor sediment from the Okinawa Trough Izena Hole and deep-sea water. The sediment sample was collected within $0-5 \mathrm{~cm}$ below the seafloor $\sim 50 \mathrm{~m}$ apart from the known hydrothermally altered area with a scoop manipulated by the remotely operated vehicle Hyper Dolphin (dive \#1185) (Miyoshi et al., 2015). Initially, $54.2 \mathrm{~g}$ of whole wet sediment, which consisted of $20.7 \mathrm{~g}$ of solids and $33.5 \mathrm{~g}$ of pore-water, and $10.3 \mathrm{~g}$ of deep seawater into the cell. Thus, $43.8 \mathrm{~g}$ of fluid was in the cell at the beginning of the experiment. The dry sediment contained $2.02 \mathrm{wt} \%$ of organic carbon with a stable carbon isotope ratio $\left(\delta^{13} \mathrm{C}_{\mathrm{org}}\right)$ of $-22.0 \%$, determined by sediment acidification for carbonate minerals removal followed by analysis with Elemental Analyzer-Isotope Ratio Mass Spectrometer (EAIRMS) as reported previously (e.g., Shao et al., 2016). The cell was pressurized and released repeatedly to remove air within the cell prior to heating. OTS was conducted at $30 \mathrm{MPa}$ and three increasing temperature stages: $275^{\circ} \mathrm{C}$ during the first 356 hours, then $320^{\circ} \mathrm{C}$ for the next 317 hours, and finally $361^{\circ} \mathrm{C}$ for 504 hours (Table 1).

Aliquots of fluid ( 3.3 to $6.6 \mathrm{~g}$ ) were withdrawn from the reaction cell for chemical analyses in glass gas-tight syringes at selected time intervals (Table 1). Fluid $\mathrm{pH}$ $\left(25^{\circ} \mathrm{C}\right)$ and dissolved gas concentrations were determined immediately after sample withdrawn. For the isotope ratio analyses at Japan Agency for Marine-Earth Science and Technology (JAMSTEC), an aliquot of the fluid was transferred into an evacuated glass vial containing mercuric chloride and butyl rubber septum cap. Prior to each sampling event, the fluid flow path was flushed by withdrawing approxiamtely $0.75 \mathrm{~g}$ of sample that was discarded.

\section{Analyses}

Dissolved concentrations of gas species and ions in the fluid samples were determined in WHOI according to methods reported previously (e.g., Seewald, 2001; Cruse and Seewald, 2006). Concentrations of total dissolved inorganic carbon $\left(\sum \mathrm{CO}_{2}\right)$ and hydrocarbons $\left(\mathrm{C}_{1}-\mathrm{C}_{4} n\right.$ alkanes, $i$-butane, and $\mathrm{C}_{2}-\mathrm{C}_{4} n$-alkenes) were determined 
Table 1. Result of OTS experiment. Chemical and isotopic composition through Okinawa Trough Sediment (OTS) experiment simulating fluid-sediment interaction under $30 \mathrm{MPa}$.

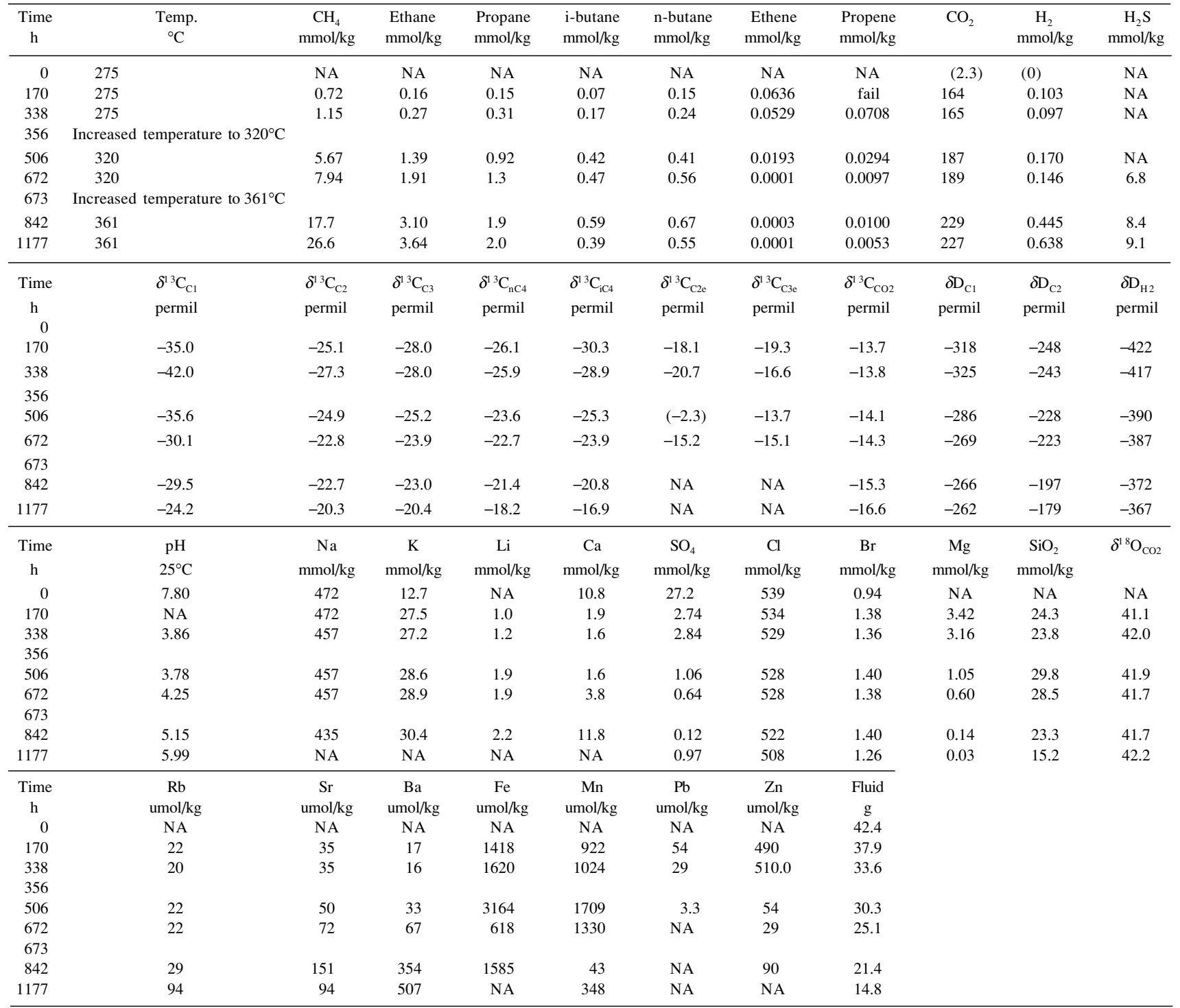

$B D=$ belowdetection.

$N A=$ notanalyzed .

using purge-and-trap Gas Chromatography (GC) with a Thermal Conductivity Detection (TCD) and Flame Ionization Detection (FID) detectors connected in series. Analytical uncertainties are $\pm 5 \%$ for $\mathrm{C}_{1}-\mathrm{C}_{4}$ alkanes and $\Sigma \mathrm{CO}_{2}$ concentrations, and $\pm 10 \%$ for alkene concentrations. Aqueous $\mathrm{H}_{2}$ concentrations were determined using a GC-TCD system with $\mathrm{N}_{2}$ carrier gas after a headspace gas extraction within a gas-tight syringe. Analytical uncertainty for the reported $\mathrm{H}_{2}$ concentrations are $\pm 10 \%$. The $\mathrm{pH}\left(25^{\circ} \mathrm{C}\right)$ was measured using an $\mathrm{Ag} / \mathrm{AgCl}$ combination reference electrode. Concentrations of major ions $\left(\mathrm{Na}^{+}, \mathrm{K}^{+}, \mathrm{Li}^{+}, \mathrm{Ca}^{2+}, \mathrm{Mg}^{2+}, \mathrm{Cl}^{-}, \mathrm{Br}^{-}\right.$, and $\left.\mathrm{SO}_{4}{ }^{2-}\right)$ were de- termined following dilution by ion chromatography with suppressed conductivity detection on a Dionex DX500 system with analytical uncertainties of $\pm 5 \%$. Concentrations of minor elements ( $\mathrm{Rb}, \mathrm{Sr}, \mathrm{Ba}, \mathrm{Si}, \mathrm{Fe}, \mathrm{Mn}, \mathrm{Pb}$, and $\mathrm{Zn})$ were determined by Inductively Coupled PlasmaMass Spectrometry (ICP-MS) with analytical uncertainties of $\pm 5 \%$. Total dissolved sulfide $\left(\mathrm{SH}_{2} \mathrm{~S}\right)$ was determined gravimetrically in selected samples following acidification of the aliquot with a $25 \mathrm{wt} . \%$ phosphoric acid solution and precipitation of the evolved $\mathrm{H}_{2} \mathrm{~S}$ gas as $\mathrm{Ag}_{2} \mathrm{~S}$ in a 5 wt. $\% \mathrm{AgNO}_{3}$ solution.

The $\delta^{13} \mathrm{C}$ and $\delta \mathrm{D}$ values of the LHCs, $\mathrm{CO}_{2}$, and $\mathrm{H}_{2}$ 
were determined by continuous-flow IRMS with an online gas purification system connected to a MAT253 mass spectrometer. The analytical procedure for $\mathrm{CH}_{4}, \mathrm{CO}_{2}$, and $\mathrm{H}_{2}$ has been presented previously in detail (Kawagucci et al., 2005, 2010; Okumura et al., 2016). For the $\delta^{13} \mathrm{C}$ analyses of $\mathrm{C}_{2}-\mathrm{C}_{4}$ hydrocarbons, the sample gas was purified by passing through a chemical trap filled with magnesium perchlorate (Merck KGaA, Darmstadt, Germany) and Ascarite II (NaOH-coated silica; Thomas Scientific, New Jersey, USA) for removal of $\mathrm{H}_{2} \mathrm{O}$ and $\mathrm{CO}_{2}$, and a stainless-steel cryogenic trap held at $-196^{\circ} \mathrm{C}$ for removal of $\mathrm{N}_{2}$ and $\mathrm{CH}_{4}$. The $\mathrm{C}_{2}-\mathrm{C}_{4}$ hydrocarbons are separated using a HP-PLOT Q capillary column (30 m long, 0.32 $\mathrm{mm}$ i.d.) with a constant flow rate at temperatures from 40 to $220^{\circ} \mathrm{C}$ and oxidized to $\mathrm{CO}_{2}$ at the combustion furnace prior to introduction into the mass spectrometer. The $\delta^{13} \mathrm{C}$ values for the $\mathrm{C}_{4+}$ alkenes cannot be quantified due to small quantities present. For the $\delta \mathrm{D}$ analysis of ethane, a stainless-steel tube filled with the Schütze reagent $\left(\mathrm{I}_{2} \mathrm{O}_{5}\right.$ on silica gel; Leco Co., St. Joseph, USA) was placed in the purification line to remove unsaturated hydrocarbons (Komatsu et al., 2005). Although we attempted to analyze the $\delta \mathrm{D}$ of $\mathrm{C}_{2+}$ hydrocarbons, they could be quantified due to baseline fluctuations. Data acquisition for all the IRMS analyses is based on the ISODAT software package. The amount of $\mathrm{H}_{3}{ }^{+}$ions generated in the ion source during hydrogen isotope analysis, the so-called $\mathrm{H}_{3}{ }^{+}$factor, was determined using ISODAT and was $<4.5(\mathrm{ppm} / \mathrm{mV})$. The analytical precisions for $\delta^{13} \mathrm{C}_{\mathrm{CH} 4}, \delta \mathrm{D}_{\mathrm{CH} 4}, \delta^{13} \mathrm{C}_{\mathrm{C} 2+}, \delta \mathrm{D}_{\mathrm{C} 2}$, $\delta^{13} \mathrm{C}_{\mathrm{CO} 2}$, and $\delta \mathrm{D}_{\mathrm{H} 2}$ values were estimated by repeated analyses of in-house standard gases to be less than $0.3 \%$, $5 \%$, $0.5 \%, 10 \%, 0.5 \%$, and $10 \%$, respectively. Values of chemical and isotopic analyses reported (Table 1) represent cumulative changes during this experiment.

\section{RESULTS}

All of the experimental results are shown in Table 1. Negligible decrease of $\mathrm{Cl}^{-}$concentration after the heating and pressurizing certifies no leakage of the reaction cell. Decrease of sulfate concentrations and non-quantitative increase of sulfide concentrations suggest sulfate mineral precipitation under the experimental condition. Concentrations of $\mathrm{K}^{+}(27.5-30.4 \mathrm{mmol} / \mathrm{kg})$ and $\mathrm{Ca}^{2+}(2-$ $12 \mathrm{mmol} / \mathrm{kg}$ ) of OTS fluids are significantly lower than those in natural hydrothermal fluids at Okinawa Trough (50-100 and 17-27 mmol/kg for $\mathrm{K}^{+}$and $\mathrm{Ca}^{2+}$, respectively) (Kawagucci, 2015; Miyazaki et al., 2017a). Concentrations of $\mathrm{Li}^{+}(1.0-2.2 \mathrm{mmol} / \mathrm{kg})$ of OTS fluids are comparable with those of natural Okinawa Trough fluids $(1.3-5.6 \mathrm{mmol} / \mathrm{kg})$. Si concentrations of OTS fluids were excess from the quartz solubility until the fifth sampling but down to the saturation level at the last sampling. This temporal $\mathrm{Si}$ behavior is consistent with those in previous
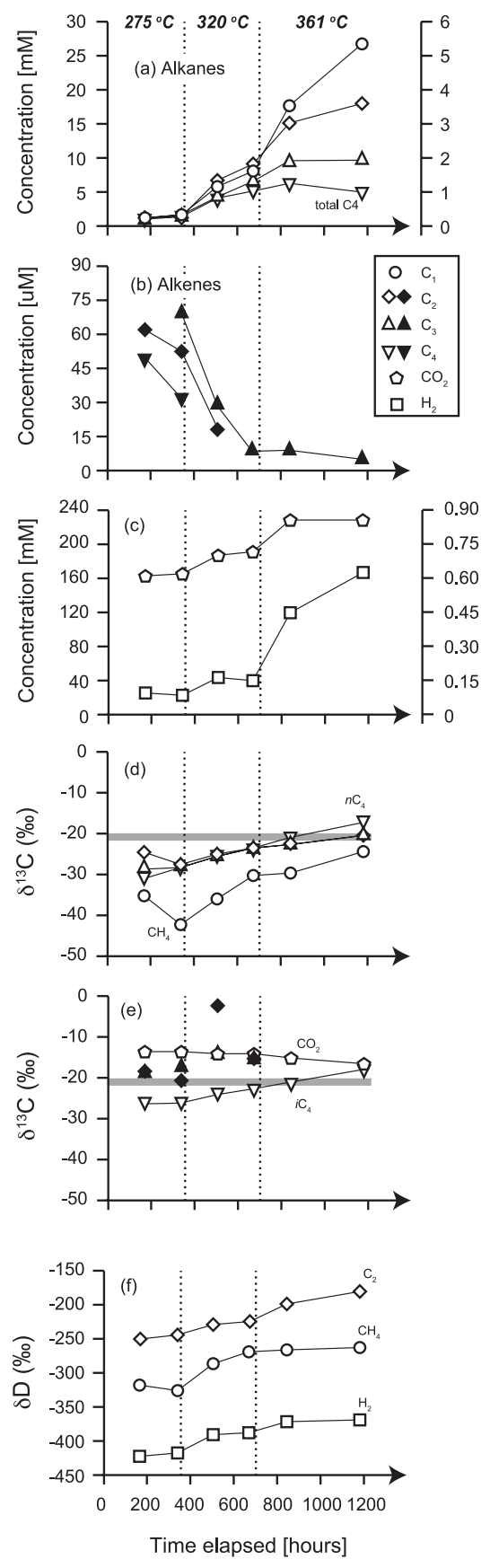

Fig. 1. Temporal variation of volatiles characteristics. (a) Concentrations of $C_{1}-C_{4}$ alkanes $\left(C_{4}\right.$ represents total of $n$ - and $i$ - $\mathrm{C}_{4} \mathrm{H}_{10}$ ), (b) Concentrations of $\mathrm{C}_{2}-\mathrm{C}_{4}$ alkenes, (c) Concentrations of $\mathrm{H}_{2}$ and $\mathrm{CO}_{2},(d) \delta^{13} \mathrm{C}$ of $\mathrm{C}_{1}-\mathrm{C}_{3}$ alkanes and $\mathrm{n}-\mathrm{C}_{4} \mathrm{H}_{10}$, (e) $\delta^{13} \mathrm{C}$ of $\mathrm{C}_{2}-\mathrm{C}_{3}$ alkenes, $i-\mathrm{C}_{4} \mathrm{H}_{10}$, and $\mathrm{CO}_{2}$, and $(f) \delta D$ of $\mathrm{CH}_{4}, \mathrm{C}_{2} \mathrm{H}_{6}$, and $\mathrm{H}_{2}$.

experiments (Seewald et al., 1990, 1994). The solubilitycontrolled Si level in the OTS last sample is also consistent with those in natural Okinawa Trough hydrothermal fluids (Kawagucci, 2015; Miyazaki et al., 2017a). 

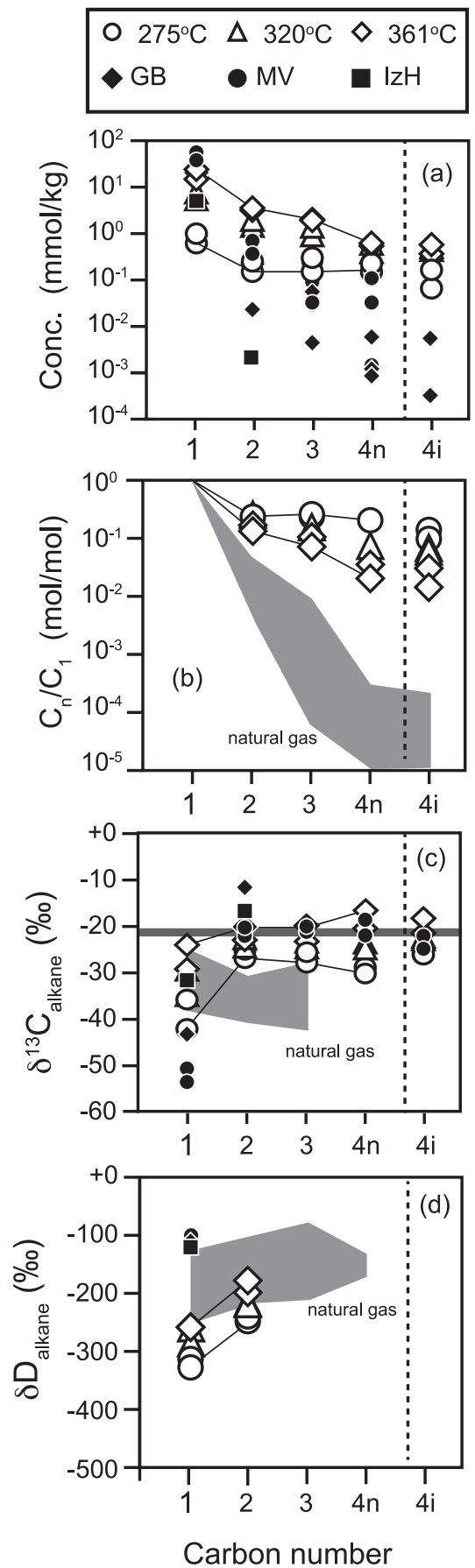

Fig. 2. Plots of compositional and isotopic characteristics of LHCs against carbon numbers. (a) Dissolved concentration (in logarithm), (b) Relative abundance of $\mathrm{C}_{2+}$ alkanes with $\mathrm{CH}_{4}$ (in logarithm), (c) $\delta^{13} C$, and (d) $\delta D$. Light grey zones in panels (b-d) represent natural gas values from (Sherwood-Lollar et al., 1994; Burruss and Laughrey, 2010). Dark grey horizontal bar in panel c represents $\delta^{13} C$ of substrate organic matter for OTS experiment. Open symbols are OTS data. Filled symbols are from natural sediment-associated hydrothermal fields $(G B$ : Guaymas Basin (Pearson et al., 2005; Proskurowski et al., 2006; McDermott et al., 2015), MV: Middle Valley (Cruse and Seewald, 2006), IzH: Izena Hole Hakurei (Ishibashi et al., 2014)).
The organic carbon content was down to $1.35 \mathrm{wt} . \%$ with $\delta^{13} \mathrm{C}_{\text {org }}$ value of $-21.5 \%$ at the end of experiment. $\mathrm{CH}_{4}$ concentrations continuously increased from 0.72 $\mathrm{mmol} / \mathrm{kg}$ in the first sample at $275^{\circ} \mathrm{C}$ to $26.6 \mathrm{mmol} / \mathrm{kg}$ in last sample at $361^{\circ} \mathrm{C}$ (Fig. 1a). Similar to $\mathrm{CH}_{4}, \mathrm{C}_{2+}$ alkane concentrations also increased with time except for total $\mathrm{C}_{4} \mathrm{H}_{10}$ which decreased in the final sample at $361^{\circ} \mathrm{C}$ (Fig. 1a). Dissolved $n$ - and $i-\mathrm{C}_{4} \mathrm{H}_{10}$ were present at similar concentrations in each sample (Table 1). The summed total of $\mathrm{C}_{1}-\mathrm{C}_{4}$ alkane concentrations increased from 1.3 $\mathrm{mmol} / \mathrm{kg}$ to $33.2 \mathrm{mmol} / \mathrm{kg}$ in the first and last samples, respectively. In general, the concentration of each $n$-alkane decreased with increasing carbon number (Fig 1a). Increases in the $\mathrm{C}_{1} / \mathrm{C}_{2+}$ ratio from 1.2 to 4.3 (Figs. $2 \mathrm{a}$ and b) reflect the rapid increases of abundance of $\mathrm{CH}_{4}$ relative to longer chain $n$-alkanes. Alkene concentrations were highest at the lower temperature earlier time period with values of $0.064 \mathrm{mmol} / \mathrm{kg}\left(\mathrm{C}_{2} \mathrm{H}_{4}\right), 0.071 \mathrm{mmol} / \mathrm{kg}\left(\mathrm{C}_{3} \mathrm{H}_{6}\right)$, and $0.049 \mathrm{mmol} / \mathrm{kg}\left(\mathrm{C}_{4} \mathrm{H}_{8}\right)$ and subsequently decreased with time and increasing temperatures (Fig. 1b). Relative to their corresponding alkanes, alkenes were present at substantially lower concentrations (Table 1). Molecular hydrogen $\left(\mathrm{H}_{2}\right)$ concentrations increased from 0.10 to 0.64 during the course of the experiment (Fig 1c). The resulting $\mathrm{H}_{2} / \mathrm{CH}_{4}$ ratio decreased with time from 0.14 to 0.024. Carbon dioxide $\left(\mathrm{CO}_{2}\right)$ was the most abundant dissolved gas present with concentrations increasing 164 $\mathrm{mmol} / \mathrm{kg}$ in the first sample at $275^{\circ} \mathrm{C}$ to $229 \mathrm{mmol} / \mathrm{kg}$ in the final sample at $361^{\circ} \mathrm{C}$ (Fig. 1c). The high $\mathrm{CO}_{2}$ concentrations likely reflect dissolution of sedimentary carbonate, decarboxylation of organic matter, and oxidation of reduced carbon species (Seewald, 2001).

The carbon isotopic composition of methane $\left(\delta^{13} \mathrm{C}_{\mathrm{CH} 4}\right)$ increased with time from $-42.0 \%$ to $-24.2 \%$ (Fig. $1 \mathrm{~d}$ ). The carbon isotopic compositions of $\mathrm{C}_{2}-\mathrm{C}_{4}$ alkanes also increased with time and ranged between $-27.3 \sim-20.3 \%$ o $\left(\delta^{13} \mathrm{C}_{\mathrm{C} 2}\right),-28.0 \sim-20.4 \% 0\left(\delta^{13} \mathrm{C}_{\mathrm{C} 3}\right),-26.1 \sim-18.2 \%$ o $\left(\delta^{13} \mathrm{C}_{n \mathrm{C} 4}\right)$, and -30.3 - $16.9 \%$ o $\left(\delta^{13} \mathrm{C}_{i \mathrm{C} 4}\right)$ (Figs. 1d and $\left.1 \mathrm{e}\right)$. In general, carbon isotope fractionation between the $\mathrm{C}_{1}-$ $\mathrm{C}_{4}$ alkanes and sedimentary organic matter was larger during the lower temperature early stages of sediment heating and smaller with increasing carbon number (Fig. 2c). The carbon isotope fractionations between $\mathrm{CH}_{4}$ and substrate organic matter, defined by $\alpha^{\mathrm{C}}{ }_{\mathrm{CH} 4-\mathrm{org}}=\left(\delta^{13} \mathrm{C}_{\mathrm{CH} 4}\right.$ $+1) /\left(\delta^{13} \mathrm{C}_{\text {org }}+1\right)$, ranged between $0.980-0.998$. The $\delta^{13} \mathrm{C}$ of the alkenes $\mathrm{C}_{2} \mathrm{H}_{4}$ and $\mathrm{C}_{3} \mathrm{H}_{6}$ showed no systematic variations with time and/or temperature and ranged between $-20.7 \sim-2.3 \%$ and $-19.3 \sim-13.7 \%$, respectively (Fig. 1e). The $\delta^{13} \mathrm{C}$ values of $\mathrm{C}_{2}-\mathrm{C}_{3}$ alkenes were always higher than those of homologous alkanes at each sampling period. The carbon isotopic composition of dissolved $\mathrm{CO}_{2}$ $\left(\delta^{13} \mathrm{C}_{\mathrm{CO} 2}\right)$ decreased from $-13.7 \%$ to $-16.6 \%$ and was accompanied by a large increase in concentration (Fig. 1e). The carbon isotope fractionations between $\mathrm{CH}_{4}$ and 
$\mathrm{CO}_{2}\left(\alpha_{\mathrm{CH} 4-\mathrm{CO} 2}^{\mathrm{C}}\right)$ got smaller from 0.971 to 0.992 with time. Isotope mass balance within the reaction cell cannot be assessed due to a lack of information regarding the ${ }^{13} \mathrm{C}$ content of solid inorganic carbon and the other organic molecules such as higher molecular weight hydrocarbons and O- and S-bearing molecules (Seewalld $e t$ al., 1990, 1994).

The hydrogen isotopic compositions of $\mathrm{CH}_{4}\left(\delta \mathrm{D}_{\mathrm{CH} 4}\right)$ increased with temperature from $-322 \%$ at $275^{\circ} \mathrm{C}$ to $-278 \%$ at $320^{\circ} \mathrm{C}$, and $-264 \%$ at $361^{\circ} \mathrm{C}$ (Fig. 1f). The resulting hydrogen isotope fractionation between $\mathrm{CH}_{4}$ and $\mathrm{H}_{2} \mathrm{O}\left(\alpha^{\mathrm{H}}{ }_{\text {CH4-H2O }}\right.$ : 0.679-0.736) was significantly lower than values estimated for $\mathrm{CH}_{4}-\mathrm{H}_{2} \mathrm{O}$ isotope equilibrium at the given temperatures $(0.879-0.888)$ (Horibe and Craig, 1995) (Fig. 3b). The isotope disequilibrium between $\mathrm{CH}_{4}$ and $\mathrm{H}_{2} \mathrm{O}$ has also been observed in experiments simulating abiotic and microbial methanogenesis (Fu et al., 2007; McCollom et al., 2010; Okumura et al., 2016) and is consistent with negligible isotope exchange between $\mathrm{CH}_{4}$ and $\mathrm{H}_{2} \mathrm{O}$ on the time scale of a year under hydrothermal conditions (Reeves et al., 2012). The hydrogen isotopic compositions of $\mathrm{C}_{2} \mathrm{H}_{6}\left(\delta \mathrm{D}_{\mathrm{C} 2}\right)$ increased with time from $-248 \%$ to $-179 \%$ (Fig. 1f). The $\delta \mathrm{D}_{\mathrm{C} 2}$ values were consistently higher than the $\delta \mathrm{D}_{\mathrm{CH} 4}$ values in each sample. The hydrogen isotopic compositions of molecular hydrogen $\left(\delta \mathrm{D}_{\mathrm{H} 2}\right)$ increased with temperature from $-422 \%$ o to $-367 \%$ o (Fig. 1f). The resulting hydrogen isotope fractionations between $\mathrm{H}_{2}$ and $\mathrm{H}_{2} \mathrm{O}\left(\alpha^{\mathrm{H}}{ }_{\mathrm{H} 2-\mathrm{H} 2 \mathrm{O}}\right.$ : 0.578-0.633) were consistent with values predicted for $\mathrm{H}_{2}-\mathrm{H}_{2} \mathrm{O}$ isotope equilibrium at the experimental temperatures (0.574-0.641) (Horibe and Craig, 1995) (Fig. 3c), suggesting that equilibrium was attained within a week under the hydrothermal condition.

\section{DiscuSSION}

\section{Hydrocarbon composition}

The production of low molecular-weight hydrocarbons (LHCs) during the thermal alteration of sedimentary organic matter involves numerous primary and secondary reactions. During the experiments presented, direct evidence for secondary reactions is provided by decreasing concentrations of alkenes with time and decreases in the concentration of $\mathrm{C}_{4}$ alkanes at the end of the $361^{\circ} \mathrm{C}$ stage of the experiment (Figs. 1a and 1b). Decomposition of $\mathrm{C}_{2+}$ aqueous hydrocarbons results in the production of shorter straight-chain hydrocarbons and carbon dioxide (Seewald, 2001). From a thermodynamics perspective, $\mathrm{C}_{2} \mathrm{H}_{6}$ decomposition at $\mathrm{H}_{2}$ concentrations of $<1 \mathrm{mM}$ and temperatures of $>275^{\circ} \mathrm{C}$ that characterized the experiments in this study should result in $\mathrm{CH}_{4}$ generation and $\mathrm{C}_{1} / \mathrm{C}_{2}$ ratio higher than $10^{7}$ (e.g., Kawagucci et al., 2013). The difference in $\mathrm{C}_{1} / \mathrm{C}_{2+}$ ratios predicted from thermodynamics and observed in OTS fluids confirms that organic matter decomposition during OTS was kinetically controlled.

A semi-log plot of $\mathrm{C}_{1}-\mathrm{C}_{4} n$-alkane concentrations against carbon numbers (Fig. 2a) has been proposed as a tool to identify abiotic origin of hydrocarbons (Etiope and Sherwood-Lollar, 2013) because chain growth by stepwise polymerization results in a linear Schulz-Flory distribution. Results of the OTS at $275^{\circ} \mathrm{C}$ showed greater $\mathrm{CH}_{4}$ enrichment relative to the Schulz-Flory trend (Fig. 2a) and likely reflects molecular heterogeneity of the substrate organic matter (e.g., lots of methyl blanches) and kinetic heterogeneity of the breaking (e.g., faster cleavage of methyl blanches). In turn, the Schulz-Flory distribution test (linear regression) for each four sample at $320-361^{\circ} \mathrm{C}$ shows good linearity $\left(r^{2} \geq 0.95\right)$ (Fig. $\left.2 \mathrm{a}\right)$. It was pointed out that a pseudo-Schulz-Flory distribution could be produced in thermogenic LHCs by random bond breaking of substrate macro organic molecular (Giggenbach, 1997). Because of absence of abiotic hydrocarbon generation under the OTS condition, the random bond breaking likely accounts for the pseudo-Schulz-Flory distribution of LHCs during the OTS at higher temperatures.

\section{Carbon isotopic composition}

The extent of carbon isotope fractionation between $\mathrm{CH}_{4}$ and sedimentary organic matter during the OTS $\left(\alpha^{\mathrm{C}}{ }_{\text {CH4-org }}=0.980-0.998\right)$ is slightly greater than those observed in a previous experiment simulating Guaymas Basin sediment alteration $\left(\alpha^{\mathrm{C}}{ }_{\mathrm{CH} 4-\mathrm{org}}=0.995-0.998\right)$ (Seewald et al., 1994). Values of $\delta^{13} \mathrm{C}_{\mathrm{CH} 4}$ for thermogenic $\mathrm{CH}_{4}$ are determined from ${ }^{13} \mathrm{C}$ content of precursor organic carbon and kinetic isotope effects. Compound- and position-specific isotope heterogeneity (Blair et al., 1987; Hayes et al., 1990; Corso and Brenna, 1997) can result in $\delta^{13} \mathrm{C}$ values for thermogenic $\mathrm{CH}_{4}$ that are substantially different than bulk $\delta^{13} \mathrm{C}_{\text {org }}$ values even if there are minor kinetic isotope effects during $\mathrm{C}-\mathrm{C}$ bond breakage. For example, environmental acetate generally showed $\sim 20 \%$ o ${ }^{13} \mathrm{C}$ depletion in its methyl carbon compared with the carboxyl carbon (Blair et al., 1987; Blair and Carter, 1992; Sugimoto and Wada, 1993). Similarly, position-specific isotope analyses of $\mathrm{C}_{5}-\mathrm{C}_{15} n$-alkanes suggested $>10 \%$ ${ }^{13} \mathrm{C}$ depletion in terminal methyl carbons compared with the internal carbons (Corso and Brenna, 1999; Gilbert et al., 2013).

The systematic approach of $\alpha^{\mathrm{C}}{ }_{\mathrm{CH} 4-\mathrm{org}}$ to a value of unity along with increasing $\mathrm{CH}_{4}$ abundance during the OTS experiment is consistent with relatively ${ }^{13} \mathrm{C}$-enriched carbon contributing to late-stage $\mathrm{CH}_{4}$ generation. This model can also explain smaller carbon isotope fractionations in $\mathrm{C}_{2+}$ alkanes (Figs. 1d and 2c). The greater fractionation in the OTS experiment relative to previous experiments examining hydrothermal alteration of Guaymas Basin sediment (Seewald et al., 1994) may re- 
flect the sampling of scheme utilized during this study that focused on the earlier stages of sediment alteration at lower temperatures that resulted in the greater release of ${ }^{13} \mathrm{C}$-depleted $\mathrm{CH}_{4}$.

A kinetic isotope effect of $\mathrm{CH}_{4}$ generation from thermal decomposition of $\mathrm{C}_{2}-\mathrm{C}_{6}$ alkanes calculated theoretically is $0.984-0.987\left(\alpha^{\mathrm{C}}{ }_{\mathrm{CH} 4-\text { precursor }}\right)$ at $327^{\circ} \mathrm{C}$ and gets greater at lower temperature (Tang et al., 2000). An experiment that simulated $\mathrm{CH}_{4}$ generation through thermal degradation of $n-\mathrm{C}_{18} \mathrm{H}_{38}$ under anhydrous conditions at $400-500^{\circ} \mathrm{C}$ also showed a significant kinetic isotope effect of $0.972-0.975\left(\alpha^{\mathrm{C}}{ }_{\mathrm{CH} 4-\mathrm{C} 18}\right)$ associated with the production of $\mathrm{CH}_{4}$ (Sackett, 1978). The magnitude of this fractionation is small in the presence of montmorillonite $\left(\alpha_{\text {CH4-C18 }}^{\mathrm{C}} \leq 0.997\right)$ (Sackett, 1978) suggesting that the extent of isotope effect is influenced by mineral catalysis. In the case of hydrothermal fluid-sediment interaction like the OTS, the reaction of aqueous LHCs may be catalyzed by water and aqueous sulfur species due to additional accessibility of alternative reaction pathways (Seewald, 2001) that similarly decline kinetic isotope effect during the production of $\mathrm{CH}_{4}$ fluid-sediment interaction. Additionally, speciation of precursor organic carbon can influence kinetic isotope effect on $\mathrm{CH}_{4}$ generation because of difference in bond enthalpies among $\mathrm{C}$ C, C-N, C-O, and so on (Smith et al., 1985).

\section{Hydrogen isotope composition}

Mechanisms controlling the D content of LHCs are more complex than those for ${ }^{13} \mathrm{C}$ because larger numbers of atoms are involved (e.g., four hydrogens per a carbon in $\mathrm{CH}_{4}$ ). Possible sources of hydrogen in thermogenic $\mathrm{CH}_{4}$ include $\mathrm{H}_{2} \mathrm{O}$ or sedimentary organic matter. In the case of methane generation form a methyl group carbon in the sedimentary organic matter, the cleavage requires one hydrogen binding from either $\mathrm{H}_{2} \mathrm{O}$ or sedimentary organic matter in addition to three native carbon-bound hydrogens. In general, the ( $\mathrm{D}$ values of marine sedimentary organic molecules $(-400 \sim-80 \%$ ) are lower than that of seawater (+0\%o) (Sauer et al., 2001; Sessions et al., 2004; Li et al., 2009). If the relative contribution of these sources is the sole factor controlling thermogenic $\delta \mathrm{D}_{\mathrm{CH} 4}$ values, a greater contribution of hydrogen derived from sedimentary organic matter would result in more negative $\delta \mathrm{D}_{\mathrm{CH} 4}$ values. The $\delta \mathrm{D}_{\mathrm{CH} 4}$ shift toward more positive values with time during the OTS experiment (Fig. 1f) can be explained by this assumption in addition to the temporal decreasing of contribution from the native methyl group-derived $\mathrm{CH}_{4}$. This is because native internal carbons in sedimentary organic matter (non-methyl group carbon) requires two or more hydrogens addition from $\mathrm{H}_{2} \mathrm{O}$ or sedimentary organic carbon to form $\mathrm{CH}_{4}$, and thus $\mathrm{H}_{2} \mathrm{O}$-derived Denriched signature would be more enhanced in the $\mathrm{CH}_{4}$ accumulated in later stage. Other factors may also regu-

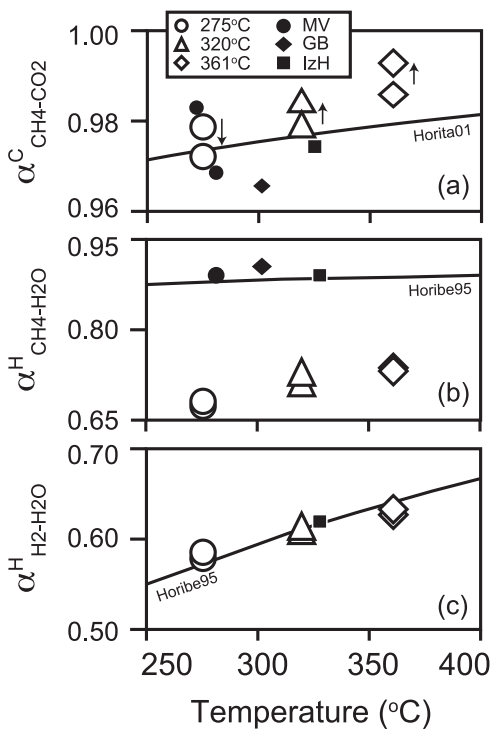

Fig. 3. Comparison of carbon and hydrogen isotope fractionations between OTS fluids and theoretical values. Each panel shows (a) $\mathrm{CH}_{4}$ and $\mathrm{CO}_{2}$ for carbon, (b) $\mathrm{CH}_{4}$ and $\mathrm{H}_{2} \mathrm{O}$ for hydrogen, and (c) $\mathrm{H}_{2}$ and $\mathrm{H}_{2} \mathrm{O}$ for hydrogen. Curves in each panel are theoretical equilibrium fractionation factors (Horibe and Craig, 1995; Horita, 2001). Symbols are same with Fig. 2. Arrows in panel (a) represent temporal trend of the change for OTS.

late the hydrogen isotope composition of $\mathrm{CH}_{4}$. For example, kinetic isotope effects and compound- and position-specific heterogeneity of the hydrogen isotope composition in bulk sedimentary organic matter may also contribute to the $\mathrm{D}$ content of $\mathrm{CH}_{4}$ as discussed for the ${ }^{13} \mathrm{C}$ content. Hydrogen isotope exchange between water and precursor organic molecules is also a factor. Although laboratory experiments have shown that exchange between $\mathrm{CH}_{4}$ and water is kinetically inhibited at the temperatures of the OTS experiment, exchange between $\mathrm{C}_{2+}$ $n$-alkanes occurs readily (Reeves et al., 2012). Accordingly, the hydrogen exchange of $\mathrm{C}_{2+} n$-alkanes and subsequent $\mathrm{LHC}$ degradation to $\mathrm{CH}_{4}$ may contribute to the isotopic composition of $\mathrm{CH}_{4}$. Nevertheless, current analytical limitation does not allow us to identify which compound/group of substrate organic matter contributes for LHCs generation and to quantify how much $\delta \mathrm{D}$ values are in each precursor compound/position.

\section{Comparison with natural hydrocarbons}

The geochemical characteristics of LHCs in the OTS fluids are distinguishable from those in the natural hydrothermal fluids venting at sediment-associated hydrothermal fields including OT sites (Pearson et al., 2005; Cruse and Seewald, 2006; Proskurowski et al., 2006; Ishibashi et al., 2014; McDermott et al., 2015; Kawagucci, 

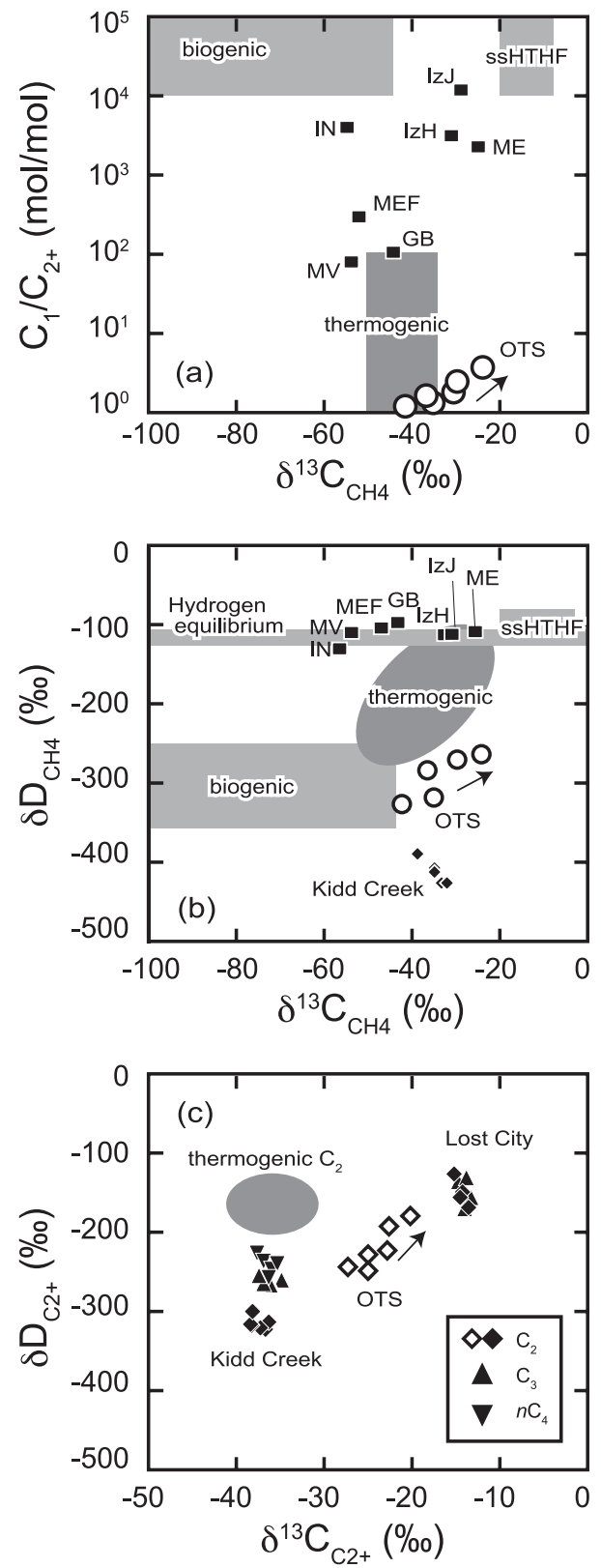

Fig. 4. Diagnostic cross plots for LHCs origins. Each panel shows (a) So-called Bernard plot, (b) C-D plot for methane, and (c) $C$-D plot for $C_{2+}$ hydrocarbons. Open circles and diamonds are OTS data. Filled symbols in panels $a$ - $b$ represent LHCs in natural geofluids of sediment-associated hydrothermal fluids (squares), sediment-non-associated fields (circles), Kidd Creek geofluid (diamonds (Sherwood Lollar et al., 2002)). Filled symbols in panel c represent LHCs in Kidd Creek geofluid (Sherwood Lollar et al., 2002) and Lost City fluid (Proskurowski et al., 2008). Dark grey zones represent thermogenic LHCs previously referred in literatures (Schoell, 1988; Whiticar, 1999; Sherwood-Lollar et al., 1994; Burruss and Laughrey, 2010). Light grey zones represent biogenic methane (Okumura et al., 2016 and references therein) or LHCs at sediment-starved hightemperature hydrothermal fields (ssHTHF) (Kawagucci et al., 2013 and references therein). Arrows in each panel represent temporal trend of the change for OTS.
2015; Toki et al., 2016; Miyazaki et al., 2017a, b). When compared with results from the OTS experiment, natural hydrothermal fluids show higher $\mathrm{C}_{1} / \mathrm{C}_{2+}$ ratio (Figs. 2a and 4a), more diverse $\delta^{13} \mathrm{C}_{\mathrm{CH} 4}$ values among the fields (Figs. 4a and $4 \mathrm{~b}$ ), higher $\delta^{13} \mathrm{C}_{\mathrm{C} 2}$ values (Fig 2c), and higher $\delta \mathrm{D}_{\mathrm{CH} 4}$ values (Fig. $4 \mathrm{~b}$ ). With increasing thermal maturity of LHCs, thermodynamically favorable $\mathrm{C}_{2+}$ degradation to $\mathrm{CH}_{4}$ leads to increasing $\mathrm{C}_{1} / \mathrm{C}_{2+}$ ratios (Fig. 4a) (see Subsubsection "Carbon isotopic composition"). The $\mathrm{C}_{2+}$ degradation and the $\mathrm{C}_{1} / \mathrm{C}_{2+}$ increase in natural fluids is likely enhanced when the fluid leaves from sedimentary organic source. The variable $\delta^{13} \mathrm{C}_{\mathrm{CH} 4}$ values among the fields may be reflected to variable stages of the maturity as seen in the OTS result. Moreover, the lower $\delta^{13} \mathrm{C}_{\mathrm{CH} 4}$ values $\left(<-40 \%\right.$ o) with higher $\mathrm{C}_{1} / \mathrm{C}_{2+}$ ratio $\left(>10^{2}\right)$ in several hydrothermal fields suggest biogenic methane contribution in addition to thermogenic LHCs (Lilley et al., 1993; Cruse and Seewald, 2006; Kawagucci et al., 2011; Toki et al., 2016). The high $\delta \mathrm{D}_{\mathrm{CH} 4}$ values of the natural fluids are similar to values predicted for the hydrogen isotope equilibrium between $\mathrm{CH}_{4}$ and $\mathrm{H}_{2} \mathrm{O}$ (Proskurowski et al., 2006; Kawagucci et al., 2013) although the isotope equilibrium was not observed during the OTS experiment and other hydrothermal experiments (Figs. 3b and 4b) (Fu et al., 2007; McCollom et al., 2010; Reeves et al., 2012). Higher $\mathrm{C}_{1} / \mathrm{C}_{2+}$ ratios and equilibrium hydrogen isotopic compositions for LHCs in the natural fluids, which are consistent with the thermodynamic prediction, may reflect longer residence time under hydrothermal condition and/or the presence of natural catalysts in solid and liquid phases within subseafloor fluid conduits.

Comparison between the OTS results and petroleum LHCs (Schoell, 1988; Sherwood Lollar et al., 1994; Burruss and Laughrey, 2010) provides additional information on how diverse the "thermogenic signature" is. The diversity results from huge difference in temperature and maturation time between the OTS $\left(\geq 275^{\circ} \mathrm{C}\right.$ for $<1200$ hours) and natural petroleum (probably $<\sim 275^{\circ} \mathrm{C}$ for $>10^{6}$ years). On a plot of relative abundance of $\mathrm{C}_{2+}$ alkanes instead of concentrations along with carbon number, natural gases show a steeper slope than the OTS fluids (Fig. 2b). The depletions in $\mathrm{C}_{2+}$ hydrocarbons relative to $\mathrm{CH}_{4}$ may reflect $\mathrm{C}_{2+}$ decomposition during thermal maturation. In general, $\delta^{13} \mathrm{C}_{\mathrm{CH} 4}$ values from the OTS show some overlap with thermogenic natural gases (Figs. $2 \mathrm{c}$ and $4 \mathrm{a}$ ). The $\delta^{13} \mathrm{C}_{\mathrm{C} 2-\mathrm{C} 3}$ values for alkanes in thermogenic natural gases are lower than observed during the OTS experiment (Fig. 2c). The $\delta \mathrm{D}$ values of $\mathrm{C}_{1}-\mathrm{C}_{2}$ alkanes of the OTS fluids are lower than those of natural gases during the early stages of the experiments, but are similar during the later stages of OTS alteration (Figs. $2 b$ and $4 b$ ). 


\section{Conclusions}

The OTS thermogenic LHCs can be explained by simultaneous occurrence of thermal generation and decomposition of LHCs and heterogeneity in bulk sedimentary organic matter with respect to its chemical and isotopic composition. The OTS experiment contributes to our understanding about geochemical processes associated with hydrothermal activity in sediment-associated fields and the origin of subsurface LHCs. On the other hand, there are some shortcomings in experimental setting of OTS. For example, OTS took only 1200 hours with frequent temperature changes although extent of the maturation is a key factor controlling compositional and isotopic characteristics of thermogenic LHCs. Another shortcoming is no information about the heterogeneity of sedimentary organic matter. Experimental simulation for fluid-sediment interaction with longer timescale than OTS and the compound-/position specific analyses for solid-phase organic source will help to cover broad spectrum and mechanisms of thermogenic signature possibly occurring subsurface environment and to improve accuracy of the geochemical diagnosis for hidden subsurface processes.

Acknowledgments-The InterRidge, a non-profit organization concerned with promoting all aspects of mid-ocean ridge research, provided the Postdoctoral fellowship in 2010 to SK for the internationally collaborative experiment in this study. We wish to thank Sean Sylva and Uta Konno for their professional assistance on the hydrothermal experiment and chemical analysis. SK would like to also thank Prof. Gretchen BernasconiGreen for providing space and opportunity to prepare the manuscript as an academic visitor of ETH Zurich in 2016.

\section{REFERENCES}

Bernard, B. B., Brooks, J. M. and Sackett, W. M. (1976) Natural gas seepage in the Gulf of Mexico. Earth Planet. Sci. Lett. 31, 48-54.

Berner, U., Faber, E., Scheeder, G. and Panten, D. (1995) Primary cracking of algal and landplant kerogens: Kinetic models of isotope variations in methane, ethane and propane. Chem. Geol. 126, 233-245.

Blair, N. E. and Carter, W. D., Jr. (1992) The carbon isotope biogeochemistry of acetate from a methanogenic marine sediment. Geochim. Cosmochim. Acta 56, 1247-1258.

Blair, N., Martens, C. and Marais Des, D. (1987) Natural abundances of carbon isotopes in acetate from a coastal marine sediment. Science 236, 66-68.

Burruss, R. C. and Laughrey, C. D. (2010) Carbon and hydrogen isotopic reversals in deep basin gas: Evidence for limits to the stability of hydrocarbons. Org. Geochem. 41, 1285-1296.

Chung, H. M., Gormly, J. R. and Squires, R. M. (1988) Origin of gaseous hydrocarbons in subsurface environments: Theoretical considerations of carbon isotope distribution. Chem. Geol. 71, 97-104.
Corso, T. N. and Brenna, J. T. (1997) High-precision positionspecific isotope analysis. Proc. Natl. Acad. Sci. USA 94, 1049-1053.

Corso, T. N. and Brenna, J. T. (1999) On-line pyrolysis of hydrocarbons coupled to high-precision carbon isotope ratio analysis. Anal. Chim. Acta 397, 217-224.

Cruse, A. M. and Seewald, J. S. (2006) Geochemistry of lowmolecular weight hydrocarbons in hydrothermal fluids from Middle Valley, northern Juan de Fuca Ridge. Geochim. Cosmochim. Acta 70, 2073-2092.

Etiope, G. and Schoell, M. (2014) Abiotic Gas: Atypical, But Not Rare. Elements 10, 291-296.

Etiope, G. and Sherwood Lollar, B. (2013) Abiotic methane on Earth. Rev. Geophys. 51, 276-299.

$\mathrm{Fu}$, Q., Sherwood Lollar, B., Horita, J., Lacrampe-Couloume, G. and Seyfried, W. E., Jr. (2007) Abiotic formation of hydrocarbons under hydrothermal conditions: Constraints from chemical and isotope data. Geochim. Cosmochim. Acta 71, 1982-1998.

Giggenbach, W. F. (1997) Relative importance of thermodynamic and kinetic processes in governing the chemical and isotopic composition of carbon gases in high-heatflow sedimentary basins. Geochim. Cosmochim. Acta 61, 3763-3785.

Gilbert, A., Yamada, K. and Yoshida, N. (2013) Exploration of intramolecular ${ }^{13} \mathrm{C}$ isotope distribution in long chain $n$ alkanes $\left(\mathrm{C}_{11}-\mathrm{C}_{31}\right)$ using isotopic ${ }^{13} \mathrm{C}$ NMR. Org. Geochem. 62, 56-61.

Hayes, J. M., Freeman, K. H., Popp, B. N. and Hoham, C. H. (1990) Compound-specific isotopic analyses: A novel tool for reconstruction of ancient biogeochemical processes. Org. Geochem. 16, 1115-1128.

Horibe, Y. and Craig, H. (1995) D/H fractionation in the system methane-hydrogen-water. Geochim. Cosmochim. Acta 59, 5209-5217.

Horita, J. (2001) Carbon isotope exchange in the system $\mathrm{CO}_{2}-$ $\mathrm{CH}_{4}$ at elevated temperatures. Geochim. Cosmochim. Acta 65, 1907-1919.

Ishibashi, J.-I., Noguchi, T., Toki, T., Miyabe, S., Yamagami, S., Onishi, Y., Yamanaka, T., Yokoyama, Y., Omori, E., Takahashi, Y., Hatada, K., Nakaguchi, Y., Yoshizaki, M., Konno, U., Shibuya, T., Takai, K., Inagaki, F. and Kawagucci, S. (2014) Diversity of fluid geochemistry affected by processes during fluid upwelling in active hydrothermal fields in the Izena Hole, the middle Okinawa Trough back-arc basin. Geochem. J. 48, 357-369.

Kawagucci, S. (2015) Fluid geochemistry of high-temperature. Subseafloor Biosphere Linked to Hydrothermal Systems: TAIGA Concept (Ishibashi, J., Okino, K. and Sunamura, M., eds.), 387-403, Springer Japan, doi:10.1007/978-4-43154865-2_30.

Kawagucci, S., Tsunogai, U., Kudo, S., Nakagawa, F., Honda, H., Aoki, S., Nakazawa, T. and Gamo, T. (2005) An analytical system for determining $\delta^{17} \mathrm{O}$ in $\mathrm{CO}_{2}$ using continuous flow-isotope ratio MS. Anal. Chem. 77, 4509-4514.

Kawagucci, S., Toki, T., Ishibashi, J., Takai, K., Ito, M., Oomori, T. and Gamo, T. (2010) Isotopic variation of molecular hydrogen in $20^{\circ}-375^{\circ} \mathrm{C}$ hydrothermal fluids as detected by a new analytical method. J. Geophys. Res. 115, G03021-9.

Kawagucci, S., Chiba, H., Ishibashi, J. I., Yamanaka, T., Toki, 
T., Muramatsu, Y., Ueno, Y., Makabe, A., Inoue, K., Yoshida, N., Nakagawa, S., Nunoura, T., Takai, K., Takahata, N., Sano, Y., Narita, T., Teranishi, G., Obata, H. and Gamo, T. (2011) Hydrothermal fluid geochemistry at the Iheya North field in the mid-Okinawa Trough: Implication for origin of methane in subseafloor fluid circulation systems. Geochem. J. 45, 109-124.

Kawagucci, S., Ueno, Y., Takai, K., Toki, T., Ito, M., Inoue, K., Makabe, A., Yoshida, N., Muramatsu, Y., Takahata, N., Sano, Y., Narita, T., Teranishi, G., Obata, H., Nakagawa, S., Nunoura, T. and Gamo, T. (2013) Geochemical origin of hydrothermal fluid methane in sediment-associated fields and its relevance to the geographical distribution of whole hydrothermal circulation. Chem. Geol. 339, 213-225.

Kawagucci, S., Kobayashi, M., Hattori, S., Yamada, K., Ueno, Y., Takai, K. and Yoshida, N. (2014) Hydrogen isotope systematics among $\mathrm{H}_{2}-\mathrm{H}_{2} \mathrm{O}-\mathrm{CH}_{4}$ during the growth of the hydrogenotrophic methanogen Methanothermobacter thermautotrophicus strain $\Delta \mathrm{H}$. Geochim. Cosmochim. Acta 142, 601-614.

Komatsu, D. D., Tsunogai, U., Yamaguchi, J. and Nakagawa, F. (2005) A selective unsaturated hydrocarbon subtraction technique for stable carbon isotopic analysis of atmospheric methyl chloride, methyl bromide, and $\mathrm{C}_{2}-\mathrm{C}_{5}$ saturated hydrocarbons using continuous-flow isotope ratio mass spectrometry. Rapid Commun. Mass Spectrom. 19, 477-483.

Li, C., Sessions, A. L., Kinnaman, F. S. and Valentine, D. L. (2009) Hydrogen-isotopic variability in lipids from Santa Barbara Basin sediments. Geochim. Cosmochim. Acta 73, 4803-4823.

Lilley, M. D., Butterfield, D. A., Olson, E. J., Lupton, J. E., Macko, S. A. and McDuff, R. E. (1993) Anomalous $\mathrm{CH}_{4}$ and $\mathrm{NH}_{4}^{+}$concentrations at an unsedimented mid-oceanridge hydrothermal system. Nature 364, 45-47.

McCollom, T. M. (1999) Methanogenesis as a potential source of chemical energy for primary biomass production by autotrophic organisms in hydrothermal systems on Europa. $J$. Geophys. Res. 104, 30729-30742.

McCollom, T. M. (2013) Laboratory simulations of abiotic hydrocarbon formation in Earth's deep subsurface. Rev. Mineral. Geochem. 75, 467-494.

McCollom, T. M. and Seewald, J. S. (2007) Abiotic synthesis of organic compounds in deep-sea hydrothermal environments. Chem. Rev. 107, 382-401.

McCollom, T. M., Lollar, B. S., Lacrampe-Couloume, G. and Seewald, J. S. (2010) The influence of carbon source on abiotic organic synthesis and carbon isotope fractionation under hydrothermal conditions. Geochim. Cosmochim. Acta 74, 2717-2740.

McDermott, J. M., Ono, S., Tivey, M. K., Seewald, J. S., Shanks, W. C., III and Solow, A. R. (2015) Identification of sulfur sources and isotopic equilibria in submarine hot-springs using multiple sulfur isotopes. Geochim. Cosmochim. Acta 160, 169-187.

Miyazaki, J., Kawagucci, S., Makabe, A., Takahashi, A., Kitada, K., Torimoto, J., Matsui, Y., Tasumi, E., Shibuya, T., Nakamura, K., Horai, S., Sato, S., Ishibashi, J.-I., Kanzaki, H., Nakagawa, S., Hirai, M., Takaki, Y., Okino, K., Watanabe, H., K., Kumagai, H. and Chen, C. (2017a) Deep- est and hottest hydrothermal activity in the Okinawa Trough: the Yokosuka site at Yaeyama Knoll. Roy. Soc. Open Sci.4, 171570-20.

Miyazaki, J., Makabe, A., Matsui, Y., Ebina, N., Tsutsumi, S., Ishibashi, J.-I., Chen, C., Kaneko, S., Takai, K. and Kawagucci, S. (2017b) WHATS-3: An improved flowthrough multi-bottle fluid sampler for deep-sea geofluid research. Front. Earth Sci. 5, 202-213.

Miyoshi, Y., Ishibashi, J., Shimada, K., Ooki, M., Uehara, S., Yoshizumi, R., Watanabe, S. and Urabe, T. (2015) Occurrence of hydrothermal alteration minerals at the Jade hydrothermal field, in the Izena Hole, mid-Okinawa Trough. Subseafloor Biosphere Linked to Hydrothermal Systems: TAIGA Concept (Ishibashi, J., Okino, K. and Sunamura, M., eds.), 567-583, Springer Japan.

Okumura, T., Kawagucci, S., Saito, Y., Matsui, Y., Takai, K. and Imachi, H. (2016) Hydrogen and carbon isotope systematics in hydrogenotrophic methanogenesis under $\mathrm{H}_{2}$-limited and $\mathrm{H}_{2}$-enriched conditions: implications for the origin of methane and its isotopic diagnosis. Prog. Earth Planet. Sci. 3, 219.

Pearson, A., Seewald, J. S. and Eglinton, T. I. (2005) Bacterial incorporation of relict carbon in the hydrothermal environment of Guaymas Basin. Geochim. Cosmochim. Acta 69 , 5477-5486.

Penning, H., Plugge, C. M., Galand, P. E. and Conrad, R. (2005) Variation of carbon isotope fractionation in hydrogenotrophic methanogenic microbial cultures and environmental samples at different energy status. Global Change Biol. 11, 2103-2113.

Prinzhofer, A. and Pernaton, E. (1997) Isotopically light methane in natural gas: bacterial imprint or diffusive fractionation? Chem. Geol. 142, 193-200.

Proskurowski, G. (2010) Abiogenic hydrocarbon production at the geosphere-biosphere interface via serpentinization reactions. Handbook of Hydrocarbon and Lipid Microbiology Springer Berlin Heidelberg, 215-231, Berlin, Heidelberg.

Proskurowski, G., Lilley, M. D., Kelley, D. S. and Olson, E. J. (2006) Low temperature volatile production at the Lost City Hydrothermal Field, evidence from a hydrogen stable isotope geothermometer. Chem. Geol. 229, 331-343.

Proskurowski, G., Lilley, M. D., Seewald, J. S., Früh-Green, G. L., Olson, E. J., Lupton, J. E., Sylva, S. P. and Kelley, D. S. (2008) Abiogenic hydrocarbon production at lost city hydrothermal field. Science 319, 604-607.

Reeves, E. P., Seewald, J. S. and Sylva, S. P. (2012) Hydrogen isotope exchange between $n$-alkanes and water under hydrothermal conditions. Geochim. Cosmochim. Acta 77, 582599.

Sackett, W. M. (1978) Carbon and hydrogen isotope effects during the thermocatalytic production of hydrocarbons in laboratory simulation experiments. Geochim. Cosmochim. Acta 42, 571-580.

Sakata, S., Sano, Y., Maekawa, T. and Igari, S.-I. (1997) Hydrogen and carbon isotopic composition of methane as evidence for biogenic origin of natural gases from the Green Tuff Basin, Japan. Org. Geochem. 26, 399-407.

Sauer, P. E., Eglinton, T. I., Hayes, J. M., Schimmelmann, A. 
and Sessions, A. L. (2001) Compound-specific D/H ratios of lipid biomarkers from sediments as a proxy for environmental and climatic conditions. Geochim. Cosmochim. Acta 65, 213-222.

Schoell, M. (1980) The hydrogen and carbon isotopic composition of methane from natural gases of various origins. Geochim. Cosmochim. Acta 44, 649-661.

Schoell, M. (1988) Multiple origins of methane in the Earth. Chem. Geol. 71, 1-10.

Seewald, J. S. (2001) Aqueous geochemistry of low molecular weight hydrocarbons at elevated temperatures and pressures: Constraints from mineral buffered laboratory experiments. Geochim. Cosmochim. Acta 65, 1641-1664.

Seewald, J. S. (2003) Organic-inorganic interactions in petroleum-producing sedimentary basins. Nature 426, 327-333.

Seewald, J. S., Seyfried, W. E., Jr. and Thornton, E. C. (1990) Organic-rich sediment alteration: an experimental and theoretical study at elevated temperatures and pressures. Appl. Geochem. 5, 193-209.

Seewald, J. S., Seyfried, W. E., Jr. and Shanks, W. C., III (1994) Variations in the chemical and stable isotope composition of carbon and sulfur species during organic-rich sediment alteration: An experimental and theoretical study of hydrothermal activity at guaymas basin, gulf of california. Geochim. Cosmochim. Acta 58, 5065-5082.

Seewald, J. S., Benitez-Nelson, B. C. and Whelan, J. K. (1998) Laboratory and theoretical constraints on the generation and composition of natural gas. Geochim. Cosmochim. Acta 62 , 1599-1617.

Sessions, A. L., Sylva, S. P., Summons, R. E. and Hayes, J. M. (2004) Isotopic exchange of carbon-bound hydrogen over geologic timescales. Geochim. Cosmochim. Acta 68, 15451559.

Seyfried, W. E., Jr., Janecky, D. R. and Berndt, M. E. (1987) Rocking autoclaves for hydrothermal experiments II. The flexible reaction-cell system. Experimental Hydrothermal Techniques (Ulmer, G. C. and Barnes, H. L., eds.), 216240, Wiley.

Shao, H., Yang, S., Cai, F., Li, C., Liang, J., Li, Q., Hyun, S., Kao, S.-J., Dou, Y., Hu, B., Dong, G. and Wang, F. (2016) Sources and burial of organic carbon in the middle Okinawa Trough during late Quaternary paleoenvironmental change. Deep-Sea Res. Part I 118, 46-56.

Sherwood Lollar, B., Weise, S. M., Frape, S. K. and Barker, J. F. (1994) Isotopic constraints on the migration of hydrocarbon and helium gases of southern Ontario. Bull. Can. Petrol. Geol. 42, 283-295.

Sherwood Lollar, B., Westgate, T. D., Ward, J. A., Slater, G. F. and Lacrampe-Couloume, G. (2002) Abiogenic formation of alkanes in the Earth's crust as a minor source for global hydrocarbon reservoirs. Nature 416, 522-524.

Smith, J. W., Rigby, D., Gould, K. W., Hart, G. and Hargraves, A. J. (1985) An isotopic study of hydrocarbon generation processes. Org. Geochem. 8, 341-347.

Stevens, T. O. and McKinley, J. P. (1995) Lithoautotrophic microbial. Science 270, 450-454.

Stolper, D. A., Lawson, M., Davis, C. L., Ferreira, A. A., Neto, E. V. S., Ellis, G. S., Lewan, M. D., Martini, A. M., Tang, Y., Schoell, M., Sessions, A. L. and Eiler, J. M. (2014) Formation temperatures of thermogenic and biogenic methane.
Science 344, 1500-1503.

Sugimoto, A. and Wada, E. (1993) Carbon isotopic composition of bacterial methane in a soil incubation experiment: Contributions of acetate and $\mathrm{CO}_{2} / \mathrm{H}_{2}$. Geochim. Cosmochim. Acta 57, 4015-4027.

Sugimoto, A. and Wada, E. (1995) Hydrogen isotopic composition of bacterial methane: $\mathrm{CO}_{2} / \mathrm{H}_{2}$ reduction and acetate fermentation. Geochim. Cosmochim. Acta 59, 1329-1337.

Takai, K., Nakamura, K., Toki, T., Tsunogai, U., Miyazaki, M., Miyazaki, J., Hirayama, H., Nakagawa, S., Nunoura, T. and Horikoshi, K. (2008) Cell proliferation at $122^{\circ} \mathrm{C}$ and isotopically heavy $\mathrm{CH}_{4}$ production by a hyperthermophilic methanogen under high-pressure cultivation. Proc. Natl. Acad. Sci. USA 105, 10949-10954.

Tang, Y., Perry, J. K., Jenden, P. D. and Schoell, M. (2000) Mathematical modeling of stable carbon isotope ratios in natural gases. Geochim. Cosmochim. Acta 64, 2673-2687.

Taran, Y. A., Kliger, G. A., Cienfuegos, E. and Shuykin, A. N. (2010) Carbon and hydrogen isotopic compositions of products of open-system catalytic hydrogenation of $\mathrm{CO}_{2}$ : Implications for abiogenic hydrocarbons in Earth crust. Geochim. Cosmochim. Acta 74, 6112-6125.

Thornton, E. C. and Seyfried, W. E., Jr. (1987) Reactivity of organic-rich sediment in seawater at $350^{\circ} \mathrm{C}, 500$ bars: experimental and theoretical constraints and implications for the Guaymas Basin hydrothermal system. Geochim. Cosmochim. Acta 51, 1997-2010.

Tissot, B. P. and Welte, D. H. (1978) Petroleum Formation and Occurrence. Springer Berlin Heidelberg, 702 pp., doi:10.1007/978-3-642-87813-8.

Toki, T., Itoh, M., Iwata, D., Ohshima, S., Shinjo, R., Ishibashi, J.-I., Tsunogai, U., Takahata, N., Sano, Y., Yamanaka, T., Ijiri, A., Okabe, N., Gamo, T., Muramatsu, Y., Ueno, Y., Kawagucci, S. and Takai, K. (2016) Geochemical characteristics of hydrothermal fluids at Hatoma Knoll in the southern Okinawa Trough. Geochem. J. 50, 493-525.

Valentine, D. L., Chidthaisong, A., Rice, A., Reeburgh, W. S. and Tyler, S. C. (2004) Carbon and hydrogen isotope fractionation by moderately thermophilic methanogens. Geochim. Cosmochim. Acta 68, 1571-1590.

Wakita, H. and Sano, Y. (1983) ${ }^{3} \mathrm{He} /{ }^{4} \mathrm{He}$ ratios in $\mathrm{CH}_{4}$-rich natural gases suggest magmatic origin. Nature 305, 792-794.

Wang, D. T., Gruen, D. S., Lollar, B. S., Hinrichs, K. U., Stewart, L. C., Holden, J. F., Hristov, A. N., Pohlman, J. W., Morrill, P. L., Konneke, M., Delwiche, K. B., Reeves, E. P., Sutcliffe, C. N., Ritter, D. J., Seewald, J. S., McIntosh, J. C., Hemond, H. F., Kubo, M. D., Cardace, D., Hoehler, T. M. and Ono, S. (2015) Nonequilibrium clumped isotope signals in microbial methane. Science 348, 428-431.

Welhan, J. A. and Lupton, J. E. (1987) Light hydrocarbon gases in Guaymas Basin hydrothermal fluids: Thermogenic versus abiogenic origin. Bulletin 71, 215-223.

Whiticar, M. J. (1999) Carbon and hydrogen isotope systematics of bacterial formation and oxidation of methane. Chem. Geol. 161, 291-314.

Whiticar, M. J., Faber, E. and Schoell, M. (1986) Biogenic methane formation in marine and freshwater environments: $\mathrm{CO}_{2}$ reduction vs. acetate fermentation-Isotope evidence. Geochim. Cosmochim. Acta 50, 693-709. 